\title{
Analisis Validitas dan Praktikalitas dari Modul Minyak Bumi Berbasis Guided Discovery Learning
} Validity and Practicality Analysis of The Petroleum Module Based on Guided Discovery Learning

W Permatasari ${ }^{1}$ and Yerimadesi ${ }^{{ }^{*}}$

${ }^{1}$ Pendidikan Kimia, Universitas Negeri Padang, Jl. Prof. Dr. Hamka, Air Tawar Barat, Padang Utara, Sumatera Barat, Indonesia 25171

*yeri@fmipa.unp.ac.id

\section{ARTICLE INFO}

Received 03 January 2020

Revised 17 January 2020

Published 06 February 2020

\begin{abstract}
The purpose of development research is to produce and analyse the validity and practicality of the guided discovery learning based on petroleum module for class XI SMA/MA. This research uses the Plomp development model. The validity test was conducted on 4 chemistry lecturers and 2 chemistry teachers. The practicality test was carried out by 2 chemists and 30 students of class XII SMA in 2019/2020. The research instrument used was a questionnaire of validity and practicality. The data obtained were analysed with Cohen's kappa formula. From the result of study obtained an average value of kappa moments of module validity $(0,89)$, module practicality by teachers $(0,93)$ and module practicality by students $(0,83)$. The data shows that the module is valid and practical for learning chemistry.
\end{abstract}

\section{KEYWORDS}

Module, Petroleum, Guided Discovery Learning, Validity, Plomp Model

\section{ABSTRAK}

Tujuan dari penelitian pengembangan ini adalah menghasilkan dan menganalisis validitas serta praktikalitas dari modul minyak bumi berbasis guided discovery learning untuk kelas XI SMA/MA. Penelitian ini menggunakan model pengembangan Plomp. Uji validitas dilakukan kepada 4 dosen kimia FMIPA UNP dan 2 guru kimia SMAN 8 Padang. Uji praktikalitas dilakukan oleh 2 guru kimia serta 30 siswa kelas XII SMAN 8 Padang pada tahun pelajaran 2019/2020. Instrumen penelitian yang digunakan berupa angket validitas dan praktikalitas. Data yang diperoleh dianalisis dengan formula kappa Cohen. Dari hasil penelitian diperoleh nilai rata-rata momen kappa validitas modul $(0,89)$, praktikalitas modul oleh guru $(0,93)$ dan praktikalitas modul oleh siswa $(0,82)$. Data tersebut memperlihatkan bahwa modul yang dihasilkan sudah valid dan praktis digunakan dalam pembelajaran.

KATA KUNCI

Modul, Minyak Bumi, Guided Discovery Learning, Validitas, Model Plomp 


\section{PENDAHULUAN}

Berdasarkan KI 3 dan KI 4 pada kurikulum kimia 2013 revisi 2017 materi minyak bumi merupakan materi yang termasuk ke dalam konsep konkret yang memiliki ranah kognitif faktual, konseptual dan prosedural. Oleh karena itu siswa dituntut untuk dapat belajar secara mandiri, terlibat aktif dalam proses pembelajaran sesuai dengan hakikat keilmuan. Berdasarkan observasi yang dilakukan di SMAN 8 Padang pada semester ganjil tahun ajaran 2019/2020 terhadap guru dan siswa diperoleh sejumlah masalah yang muncul dalam kegiatan pembelajaran minyak bumi. Masalah tersebut seperti (1) terbatasnya modul yang mampu membimbing siswa agar dapat belajar dengan mandiri; (2) rendahnya aktivitas siswa pada proses pembelajaran; (3) siswa masih cenderung menghafal konsep-konsep inti dalam pembelajaran minyak bumi. Masalah ini bertentangan dengan kurikulum 2013 revisi 2017. Maka dari itu untuk mencapai tuntutan tersebut diperlukan suatu bahan ajar dengan model pembelajaran sesuai pendekatan saintifik yang dapat membimbing siswa dalam penemuan konsep agar pembelajaran lebih bermakna. Salah satu model pembelajaran yang bisa digunakan pada mata pelajaran kimia sesuai dengan kurikulum 2013 adalah model pembelajaran guided discovery ${ }^{[1]}$.

Guided discovery learning adalah suatu model yang berpusat pada penemuan konsep dan prinsip oleh siswa dengan bimbingan dari guru, sehingga siswa lebih terlibat aktif dalam kegiatan belajar serta mampu meningkatkan prestasi belajarnya. Hal ini sesuai dengan penelitian yang mengungkapkan bahwa model guided discovery learning efektif dalam memfasilitasi pencapaian prestasi siswa dalam pembelajaran fisika setelah diberikan organizer bergambar beserta demonstrasi ${ }^{[2]}$. Selain itu penerapan model pembelajaran guided discovery learning menggunakan bantuan virtual laboratory PhET dapat mengembangkan prestasi siswa dalam pembelajaran teori kinetik gas. Hal tersebut dibuktikan dalam ranah kognitif, N-Gain yang diperoleh pada kelas percobaan adalah 0,7 dengan kategori tinggi dan untuk kelas replikasi 1 dan 2 secara berurutan adalah 0,4 (rendah) dan 0,6 (sedang). Pada proses pembelajaran dengan model guided discovery learning siswa terlihat lebih berpartisipasi dan berani dalam mengajukan pendapatnya, hal tersebut ditunjukkan oleh nilai persentase keterlibatan siswa pada kelas percobaan meningkat sebanyak $85,42 \%{ }^{[3]}$.

Keaktifan siswa dalam proses belajar dengan tidak langsung mampu melatih kemampuan berpikir kritisnya. Salah satu faktor pendukung untuk meningkatkan keaktifan dan kemandirian siswa adalah penggunaan modul dalam proses pembelajaran. Pengembangan modul sebagai bahan ajar bertujuan untuk meningkatkan ketertarikan dan keterlibatan siswa pada topik yang dipelajari, sehingga kegiatan pembelajaran akan menjadi lebih efektif. Selain itu penggunaan modul menjadi salah satu aspek yang mampu membantu guru untuk mengajarkan suatu topik dalam mata pelajaran tertentu kepada siswa ${ }^{[4]}$. Hal tersebut karena pembelajaran dengan modul mampu membangkitkan motivasi belajar dari dalam diri siswa, salah satunya dalam pembelajaran kimia. Dorongan belajar dari dalam diri siswa yang telah menggunakan modul lebih signifikan dari pada pembelajaran dengan cara konvensional ${ }^{[5]}$.

Penyusunan modul dengan model guided discovery learning mampu mengembangkan serta menggali kemampuan peserta didik khususnya keterampilan proses sains untuk menemukan fakta, prinsip dan konsep ${ }^{[6]}$. Selain itu modul yang berbasis guided discovery learning juga mampu meningkatkan prestasi belajar siswa ${ }^{[7]}$. Namun modul minyak bumi berbasis guided discovery learning untuk Kelas XI SMA belum tersedia. Dengan demikian dilakukanlah suatu penelitian yang bertujuan untuk mengembangkan modul minyak bumi berbasis guided discovery learning dan menganalisis tingkat validitas serta praktikalitasnya.

\section{METODE}

Jenis penelitian ini adalah penelitian dan pengembangan yang disebut juga Research and Development $(\mathrm{R} \& \mathrm{D})$ dengan menggunakan model pengembangan Plomp oleh Tjreed Plomp. Model pengembangan ini mencakup tiga langkah penelitian berupa penelitian pendahuluan (preliminary research), pembentukan prototipe (prototyping stage) dan penilaian (assessment phase) ${ }^{[8]}$.

Produk yang dikembangkan dalam penelitian ini adalah modul minyak bumi berbasis guided discovery learning untuk siswa SMA kelas XI. Uji coba produk dilakukan di SMAN 8 Padang kepada siswa kelas XII IPA dengan 3 kali pertemuan. Penelitian dilaksanakan sejak bulan Mei sampai bulan Desember 2019. Subjek dari penelitian ini yaitu 4 orang dosen kimia FMIPA UNP, 2 orang guru kimia dan 30 orang siswa kelas XII SMA N 8 Padang. Dosen dan guru kimia bertindak sebagai validator, serta guru kimia dan siswa kelas XII bertindak sebagai penilai praktikalitas. Prosedur penelitian pengembangan modul minyak bumi berbasis guided discovery learning untuk SMA kelas XI menggunakan model penelitian Plomp dijelaskan sebagai berikut.

\subsection{Tahap Penelitian Pendahuluan}

Dalam tahap penelitian pendahuluan dilakukan kegiatan analisis kebutuhan, analisis konteks, studi literatur dan mengembangkan kerangka konseptual untuk penelitian. Kegiatan yang dilakukan berupa (a) analisis kebutuhan, pada tahap ini dilakukan observasi melalui penyebaran angket kepada siswa kelas XII dan wawancara terhadap guru kimia SMAN 8 Padang. Selain itu juga dilakukan tinjauan jurnal-jurnal yang berkaitan dengan penelitian; (b) analisis konteks, pada tahap ini dilakukan analisis kurikulum dan silabus yang digunakan. Langkah pertama yang dilakukan yaitu menganalisis 
KD untuk menentukan kemampuan mendasar yang seharusnya dikuasai oleh siswa pada materi minyak bumi. Dari hasil analisis KD selanjutnya dirumuskan indikator pencapaian kompetensi yang menjadi acuan dari tujuan pembelajaran; (c) studi literatur, pada tahap ini dilakukan pencarian dan pengumpulan sumber-sumber referensi yang akan digunakan dalam penelitian; (d) pengembangan kerangka konseptual, pada tahap ini kegiatan yang dilakukan adalah mengurutkan dan merangkai konsep-konsep yang akan dipelajari siswa dengan penyajian yang sistematis.

\subsection{Tahap Pembentukan Prototipe}

Dalam tahap pembentukan prototipe dilakukan kegiatan merancang dan merealisasikan modul yang dikembangkan. Langkah-langkah yang dikerjakan dalam tahap ini dijelaskan seperti berikut: (a) prototipe 1 , dilakukan perancangan produk dengan bentuk bahan ajar berupa modul minyak bumi berbasis guided discovery learning yang didasarkan pada kurikulum 2013 revisi 2017. Hal-hal yang dikerjakan pada kegiatan ini yaitu: perancangan bahan ajar berupa modul sesuai dengan sintak guided discovery learning ${ }^{[1]}$ dan format penulisan bahan ajar sesuai panduan sistem pengajaran dengan modul Suryosubroto ${ }^{[9]}$ dan panduan pengembangan bahan ajar yang ditetapkan oleh Departemen Pendidikan Nasional ${ }^{[10]}$. Setelah perancangan selesai dilanjutkan dengan tahap merealisasikan rancangan yang dibuat untuk menghasilkan prototipe I; (b) prototipe II, dilakukan evaluasi formatif yaitu self evaluation (evaluasi diri sendiri) pada prototipe I yang telah dirancang sebelumnya. Self evaluation dilakukan dengan menceklis poin-poin yang harus terdapat pada modul yang telah dirancang. Apabila poin-poin pada modul masih kurang maka dilakukan revisi sehingga menghasilkan prototipe II yang lengkap; (c) prototipe III, pada kegiatan ini dilakukan uji coba satu-satu (one-to-one evaluation) serta penilaian ahli (expert review) pada prototipe II yang dihasilkan; (d) prototipe IV, pada tahap ini dilakukan evaluasi terhadap prototipe III yang sudah valid melalui uji coba kelompok kecil (small group). Hal ini bertujuan untuk mengetahui kepraktisan dari modul yang telah dikembangkan. Uji coba ini dilakukan terhadap 6 orang siswa kelas XII IPA SMAN 8 Padang dengan kemampuan yang berbeda, yaitu dari yang tinggi hingga ke yang rendah.

\subsection{Tahap Penilaian}

Pada tahap penilaian dilakukan evaluasi semi-sumatif agar diperoleh kesimpulan tentang bagaimana penggunaan modul yang dihasilkan dalam praktik lapangan. Uji lapangan (field test) yang dilakukan bertujuan demi meningkatkan tingkat praktikalitas prototipe IV yang diperoleh. Uji praktikalitas dilakukan melalui pemberian angket terhadap guru kimia SMA dan siswanya. Selanjutnya dilakukan analisis terhadap data validitas dan praktikalitas yang diperoleh menggunakan formula kappa Cohen ${ }^{[11]}$.

$$
\text { momen kappa }(k)=\frac{\rho_{0}-\rho_{e}}{1-\rho_{e}}
$$

\section{Keterangan}

$k=$ momen kappa

$\rho_{0}=$ nilai yang terealisasi, diperoleh dengan cara jumlah nilai yang diberi oleh validator dibagi jumlah nilai maksimal

$\rho_{e}=$ nilai yang tidak terealisasi, diperoleh dengan cara jumlah nilai maksimal dikurangi dengan jumlah nilai total yang diberi validator dibagi jumlah nilai maksimal

Kategori penilaian yang didasarkan pada momen kappa dapat dilihat pada Tabel 1.

Tabel 1. Kategori penilaian berdasarkan momen $\operatorname{Kappa}(k)^{[11]}$

\begin{tabular}{c|c} 
Rentang & Kategori \\
\hline$<0,00$ & Tidak valid \\
\hline $0,01-0,20$ & Sangat rendah \\
\hline $0,21-0,40$ & Rendah \\
\hline $0,41-0,60$ & Sedang \\
\hline $0,61-0,80$ & Tinggi \\
\hline $0,81-1,00$ & Sangat tinggi
\end{tabular}

Teknik analisis jawaban siswa didasarkan kepada teknik persentase yang dinyatakan sebagai berikut ini ${ }^{[12]}$.

$$
P=\frac{\text { skor yang diperoleh }}{\text { skor maksimal }} \times 100 \%
$$

Keterangan

$\mathrm{P}=$ persentase aktivitas

Nilai yang didapatkan diinterpretasikan sesuai dengan kriteria seperti pada Tabel 2.

Tabel 2. Kriteria kualitas persentase ${ }^{[12]}$

\begin{tabular}{c|c|c} 
No & $\begin{array}{c}\text { Rentang } \\
\text { Persentase }\end{array}$ & Kategori \\
\hline 1 & $81-100$ & Sangat baik \\
\hline 2 & $61-80$ & Baik \\
\hline 3 & $41-60$ & Cukup baik \\
\hline 4 & $21-40$ & Rendah \\
\hline 5 & $0-20$ & Sangat rendah
\end{tabular}

\section{HASIL DAN DISKUSI}

\subsection{Tahap Penelitian Pendahuluan}

Pada tahap penelitian pendahuluan diperoleh data hasil analisis kebutuhan, analisis konteks, studi literatur dan pengembangan kerangka konseptual. Hasil dari setiap tahapan dijelaskan sebagai berikut ini. 


\subsubsection{Analisis Kebutuhan}

Berdasarkan hasil analisis kebutuhan melalui observasi lapangan diperoleh informasi bahwa siswa dalam pembelajaran minyak bumi masih bersifat menghafal dan membutuhkan bimbingan untuk menemukan konsep-konsep yang terdapat pada materi minyak bumi. Kebiasaan menghafal merupakan tingkatan terendah dari kemampuan berpikir menurut bloom sehingga hal tersebut menyebabkan rendahnya keterlibatan dan kemandirian siswa dalam pembelajaran.

Oleh karena itu, untuk meningkatkan kemandirian dan melatih kemampuan berpikir siswa dikembangkanlah modul minyak bumi berbasis guided discovery learning karena penggunaan modul dalam kegiatan belajar kimia di sekolah masih sebesar $11 \%$, sedangkan penggunaan modul dalam kegiatan pembelajaran mampu mendukung siswa untuk dapat belajar secara mandiri dengan maupun tanpa arahan guru ${ }^{[13]}$.

\subsubsection{Analisis Konteks}

Hasil analisis kurikulum dan silabus yang diperoleh pada tahap ini berupa perumusan KD menjadi IPK yang selanjutnya dirumuskan menjadi tujuan pembelajaran. $\mathrm{KD}$ yang dianalisis adalah $\mathrm{KD}$ 3.2 menjelaskan proses pembentukan fraksi-fraksi minyak bumi, teknik pemisahan serta kegunaannya; 3.3 memahami reaksi pembakaran hidrokarbon yang sempurna dan tidak sempurna serta sifat zat hasil pembakaran (CO2, CO, Partikulat karbon); 4.2 menyajikan karya tentang proses pembentukan dan teknik pemisahan fraksi-fraksi minyak bumi beserta kegunaannya; 4.3 menalar dampak pembakaran senyawa hidrokarbon terhadap lingkungan dan kesehatan serta mengajukan gagasan cara mengatasinya. Berdasarkan KD tersebut dirumuskan IPK sebagai berikut: 3.2.1 menjelaskan proses pembentukan minyak bumi; 3.2.2 Menjelaskan teknik pemisahan fraksifraksi minyak bumi; 3.2.3 menjelaskan kegunaan dari fraksi-fraksi minyak bumi; 3.3.1 membedakan reaksi pembakaran hidrokarbon yang sempurna dan tidak sempurna; 3.3.2 menjelaskan sifat zat hasil pembakaran (CO2, CO, Partikulat karbon); 4.2.1 mempresentasikan hasil pemahaman tentang proses pembentukan fraksi-fraksi minyak bumi, teknik pemisahan dan kegunaannya; 4.3.1 menentukan dampak pembakaran bahan bakar terhadap lingkungan dan kesehatan; 4.3.2 menentukan cara mengatasi dampak dari pembakaran bahan bakar.

\subsubsection{Studi Literatur}

Hasil dari studi literatur yang dilakukan yaitu: (1) model guided discovery learning terdiri dari lima sintak berupa motivasi dan presentasi masalah (motivation and problem presentation), pengumpulan data (data collection), pengolahan data (data processing), verifikasi (verification) dan kesimpulan (closure) ${ }^{[1]}$; (2) modul yang terdiri dari beberapa komponen hasil modifikasi dari format penulisan bahan ajar sesuai panduan sistem pengajaran dengan modul Suryosubroto[9] dan panduan pengembangan bahan ajar yang ditetapkan oleh Departemen Pendidikan Nasional[10] yaitu cover, petunjuk belajar (petunjuk untuk guru dan peserta didik), kompetensi yang harus dicapai, lembar kegiatan siswa, lembar kerja, kunci lembar kerja, lembar evaluasi, kunci lembar evaluasi; (3) model penelitian dalam pengembangan modul menggunakan model pengembangan plomp yang terdiri atas dari 3 langkah seperti: preliminary research, prototyping stage, assessment phase $e^{[8]}$; (4) penelitian-penelitian yang relevan.

\subsubsection{Pengembangan Kerangka Konseptual}

Hasilyang diperoleh pada tahap pengembangan kerangka konseptual adalah tabel analisis konsep yang terdiri dari konsep-konsep penting dari materi minyak bumi. Analisis konsep yang telah diperoleh dijadikan acuan dalam merumuskan peta konsep dan penyusunan materi dalam modul.

\subsection{Tahap Pembentukan Prototipe}

Hasil prototyping stage yang dilakukan melalui evaluasi formatif yaitu pembentukan empat prototipe. Hasil dari setiap prototipe dijelaskan berikut ini.

\subsubsection{Prototipe $I$}

Prototipe I yang dihasilkan berupa perancangan modul minyak bumi berbasis guided discovery learning ${ }^{11}$ yang didasarkan pada kurikulum 2013 revisi 2017 dengan format penulisan bahan ajar yang merupakan modifikasi dari panduan sistem pengajaran dengan modul Suryosubroto ${ }^{[9]}$ dan panduan pengembangan bahan ajar yang ditetapkan oleh Departemen Pendidikan Nasional ${ }^{[10]}$. Hasil rancangan prototipe I mencakup komponen dari modul seperti (a) cover modul, yang terdiri dari beberapa bagian seperti judul modul, sasaran pengguna, nama penulis, dosen pembimbing, instansi penulis dan gambar pendukung; (b) petunjuk penggunaan modul, merupakan suatu pedoman yang dibutuhkan oleh guru dan siswa dalam menggunakan modul minyak bumi berbasis guided discovery learning yang telah dikembangkan; (c) kompetensi yang akan dicapai, penyajian KI, KD dijadikan sebagai dasar untuk menentukan kompetensi minimal yang harus dicapai oleh siswa dalam kegiatan pembelajaran minyak bumi; (d) lembar kegiatan yang terdiri dari materi yang harus dikuasai oleh siswa dan berdasar pada IPK yang telah dirumuskan; (e) lembar kerja siswa, bagian ini berisi soal-soal latihan yang berguna untuk memantapkan konsep; (f) lembar evaluasi, soal-soal evaluasi yang disajikan didasarkan pada semua IPK dalam pembelajaran. Hasil yang diperoleh oleh siswa dalam menjawab soal evaluasi dapat digunakan sebagai alat ukur ketercapaian dari tujuan pembelajaran; (g) kunci lembar kerja siswa serta lembar evaluasi, kunci ini dapat dijadikan oleh siswa sebagai alat pembanding untuk melihat bagaimana hasil belajarnya pada materi minyak bumi. 


\subsubsection{Prototipe II}

Hasil prototipe II diperoleh melalui self evaluation terhadap prototipe I yang dirancang, yaitu didapatkan daftar komponen-komponen lengkap dari modul. Komponen-komponen modul yang digunakan berdasarkan pada format penulisan bahan ajar sesuai panduan sistem pengajaran dengan modul dengan langkah pembelajaran yang sesuai sintak guided discovery learning.

\subsubsection{Prototipe III}

Pada tahap ini diperoleh hasil evaluasi formatif terhadap prototipe II. Hasil evaluasi formatif didasarkan dari expert review (penilaian ahli) dan one to one evaluation (uji coba satu-satu) yang dijelaskan di bawah ini.

\subsubsection{Penilaian Ahli}

Hasil penilaian ahli oleh 4 orang dosen kimia FMIPA UNP serta 2 orang guru kimia SMAN 8 Padang diperoleh kategori validitas dari modul minyak bumi berbasis guided discovery learning. Informasi ini dapat dilihat pada Tabel 3. Validasi suatu produk dapat menggunakan minimal 3 orang pakar ${ }^{[14]}$. Aspek yang dinilai terhadap modul yang dikembangkan mencakup: komponen isi, kebahasaan, penyajian dan kegrafikaan ${ }^{[10]}$.

Tabel 3. Hasil analisis validitas modul

\begin{tabular}{c|c|c|c} 
No & $\begin{array}{c}\text { Aspek } \\
\text { Penilaian }\end{array}$ & $\mathbf{k}$ & Kategori \\
\hline 1 & Isi & 0,88 & $\begin{array}{c}\text { Sangat } \\
\text { tinggi }\end{array}$ \\
\hline 2 & Kebahasaan & 0,86 & $\begin{array}{c}\text { Sangat } \\
\text { tinggi }\end{array}$ \\
\hline 3 & Penyajian & 0,89 & $\begin{array}{c}\text { Sangat } \\
\text { tinggi }\end{array}$ \\
\hline 4 & Kegrafikaan & 0,92 & $\begin{array}{c}\text { Sangat } \\
\text { tinggi }\end{array}$ \\
\hline \multicolumn{2}{|c|}{ Rata-rata } & $\mathbf{0 , 8 9}$ & $\begin{array}{c}\text { Sangat } \\
\text { tinggi }\end{array}$
\end{tabular}

Berdasarkan Tabel 3 diperoleh informasi bahwa secara keseluruhan aspek penilaian modul minyak bumi memiliki kategori yang sangat tinggi. Validitas komponen isi modul minyak bumi berbasis guided discovery learning yang dikembangkan memiliki momen kappa sebesar 0,88. Informasi tersebut mengungkapkan bahwa modul yang dihasilkan telah sesuai dengan KD dalam kurikulum. Bagian-bagian yang terdapat dalam komponen isi seperti isi modul, gambar dan soal-soal sudah sesuai dengan indikator pencapaian kompetensi. Dalam penyusunan suatu modul, materi harus disajikan sesuai dengan KD yang akan dicapai siswa sesuai dengan kurikulum yang digunakan serta dapat mengarahkan siswa sehingga siswa mampu belajar dan mengerjakan tugas-tugasnya. Modul yang baik adalah modul yang dapat menggambarkan KD yang akan dicapai oleh siswa ${ }^{[10]}$.
Validitas komponen kebahasaan modul minyak bumi berbasis guided discovery learning mempunyai momen kappa sebesar 0,86. Keadaan tersebut mengungkapkan bahwa bentuk dan ukuran huruf jelas dan terbaca, informasi yang terdapat pada modul bisa dimengerti dan sesuai menurut ejaan bahasa indonesia. Modul yang baik merupakan modul yang dapat menguraikan sesuatu menggunakan bahasa yang dapat dipahami oleh siswa berdasarkan tingkatan pengetahuan dan usianya $^{[10]}$. Komponen kebahasaan dengan kategori validasi yang sangat tinggi menunjukkan bahwa bahasa yang terdapat pada modul sudah sesuai dengan tingkat perkembangan dan penguasaan siswa $^{[15]}$. Oleh karena itu modul dari segi kebahasaan dinyatakan layak dijadikan sebagai bahan ajar dalam kegiatan belajar.

Validitas komponen penyajian modul minyak bumi berbasis guided discovery learning mempunyai momen kappa sebesar 0,86. Keadaan tersebut mengungkapkan bahwa isi modul yang dihasilkan telah sistematis dan sesuai dengan sintak guided discovery learning. Lembar kegiatan pada modul mampu mendukung siswa agar dapat menemukan konsep-konsep penting pada pembelajaran minyak bumi. Soal-soal pada bagian LKS dan lembar evaluasi dalam modul mampu mengarahkan siswa untuk mencapai tujuan pembelajaran, sehingga bisa digunakan sebagai alat ukur tercapainya tujuan pembelajaran. Komponen penyajian yang memiliki kategori kevalidan sangat tinggi menunjukkan bahwa penyusunan modul telah mengacu terhadap tujuan pembelajaran yang jelas ${ }^{[16]}$.

Validitas komponen kegrafikaan modul minyak bumi berbasis guided discovery learning mempunyai momen kappa sebesar 0,92. Hal ini menunjukkan bahwa desain modul secara umum sudah menarik, gambar serta ilustrasi yang disajikan bisa diamati dengan jelas. Modul yang disusun secara menarik mampu meningkatkan motivasi siswa untuk membaca materi dalam pembelajaran ${ }^{[17]}$. Oleh karena itu komponen kegrafikaan dalam pengembangan modul adalah satu bagian penting untuk menarik minat membaca siswa.

Rata-rata momen kappa validitas dari modul adalah sebesar 0,89. Hal tersebut menunjukkan bahwa modul minyak bumi berbasis guided discovery learning yang dihasilkan sesuai dengan standar pengembangan bahan ajar yang ditetapkan oleh Departemen Pendidikan Nasional yang dibuktikan dengan penilaian yang diberikan oleh 6 orang validator modul tersebut. Berdasarkan informasi tersebut diperoleh kesimpulan bahwa modul minyak bumi berbasis guided discovery learning dapat digunakan sebagai bahan ajar dalam kegiatan pembelajaran. Keadaan tersebut juga sejalan dengan hasil penelitian yang menyatakan bahwa beberapa modul berbasis guided discovery learning yang dikembangkan untuk pembelajaran kimia seperti materi kesetimbangan kimia ${ }^{[16]}$; asam basa ${ }^{[18]}$; reaksi redoks dan sel elektrokimia ${ }^{[7]}$ memiliki kategori kevalidan dan kepraktisan yang sangat tinggi. Oleh 
karena itu modul ini bisa dijadikan sebagai bahan ajar dalam kegiatan pembelajaran kimia di SMA.

\subsubsection{Uji Coba satu-satu}

Hasil wawancara yang diperoleh pada uji coba satu-satu terhadap 3 orang siswa yang mempunyai kemampuan berbeda yaitu tinggi, sedang dan rendah dapat dilihat gambaran bahwa prototipe II yang dihasilkan sudah baik. Berdasarkan analisis jawaban siswa yang diperoleh menunjukkan bahwa prototipe II dari modul yang dihasilkan sudah baik dilihat dari segi susunan materi, langkah-langkah kegiatan pembelajaran, soal-soal latihan, desain dan tampilan modul yang mampu mendukung siswa memahami materi dalam modul.

\subsubsection{Prototipe $I V$}

Hasil evaluasi formatif terhadap prototipe III pada tahap ini diperoleh melalui uji small group. Uji kelompok kecil yang dilakukan oleh 6 orang siswa dengan kemampuan yang berbeda, yaitu tinggi, sedang dan rendah menghasilkan momen kappa untuk aspek kemudahan penggunaan, efisiensi waktu dan manfaat secara berturut-turut yaitu 0,90 ; 0,87 dan 0,87 dengan kategori semuanya sangat tinggi.

Keadaan tersebut diperkuat oleh kemampuan siswa mengerjakan lembar kegiatan pada modul. Hasil analisis jawaban siswa dalam setiap tahapan yang terdapat dalam lembar kegiatan dapat dilihat pada Tabel 4 .

Tabel 4. Analisis jawaban siswa pada modul

\begin{tabular}{|c|c|c|c|}
\hline No & $\begin{array}{c}\text { Aspek } \\
\text { Penilaian }\end{array}$ & $\begin{array}{l}\text { Nilai } \\
\text { rata-rata }\end{array}$ & Kategori \\
\hline 1 & $\begin{array}{c}\text { Kemampuan } \\
\text { merumuskan } \\
\text { hipotesis }\end{array}$ & 83,75 & Sangat baik \\
\hline 2 & $\begin{array}{c}\text { Kemampuan } \\
\text { melakukan } \\
\text { pengolahan } \\
\text { data }\end{array}$ & 80,21 & Baik \\
\hline 3 & $\begin{array}{c}\text { Kemampuan } \\
\text { melakukan } \\
\text { verifikasi }\end{array}$ & 79,25 & Baik \\
\hline 4 & $\begin{array}{l}\text { Kemampuan } \\
\text { melakukan } \\
\text { kesimpulan }\end{array}$ & 82,88 & Sangat baik \\
\hline
\end{tabular}

Hasil analisis jawaban siswa pada uji small group menunjukkan bahwa secara umum siswa mampu menemukan dan memahami konsep-konsep pada materi minyak bumi dalam modul dengan kategori baik dan sangat baik.

\subsection{Tahap Penilaian}

Berdasarkan hasil penilaian praktikalitas dari guru dan siswa (field test) diperoleh rata-rata momen kappa praktikalitas field test dari guru dan siswa secara berturut-turut yaitu 0,93 dan 0,82 dengan kategori sangat tinggi. Data tersebut mengungkapkan bahwa modul yang dihasilkan telah praktis dari aspek kemudahan penggunaan, efisiensi waktu dan manfaat.

a. Analisis Praktikalitas Berdasarkan Angket Respon Guru

Dari segi kemudahan pengguna, modul minyak bumi berbasis guided discovery learning yang dikembangkan diperoleh nilai momen kappa yaitu 0,96 dengan kategori sangat tinggi. Data tersebut mengungkapkan bahwa modul minyak bumi berbasis guided discovery learning yang dikembangkan mempunyai petunjuk penggunaan modul yang mudah dimengerti, topik pembelajaran disajikan dengan jelas dan sederhana, bahasa dalam modul mudah dimengerti dan langkah-langkah pembelajaran dalam modul jelas. Keadaan tersebut sesuai dengan gagasan yang menyatakan bahwa modul harus dapat menyalurkan informasi serta memberikan petunjuk penggunaan yang jelas mengenai hal-hal yang akan dikerjakan oleh siswa ${ }^{[19]}$. Dari penjelasan di atas diperoleh kesimpulan bahwa modul yang bermakna merupakan modul yang bisa dengan mudah digunakan oleh siswa.

Dari segi efisiensi waktu belajar, modul minyak bumi berbasis guided discovery learning yang dikembangkan diperoleh nilai momen kappa yaitu 0,93 dengan kategori sangat tinggi. Data tersebut menggambarkan jika modul yang dihasilkan mampu membuat siswa untuk belajar sesuai dengan kecepatannya masing-masing sehingga efisiensi waktu belajar siswa menjadi lebih baik. Keadaan ini juga didukung oleh hasil penelitian yang menyatakan bahwa modul bisa menjadikan waktu pembelajaran lebih efisien ${ }^{[16]}$. Hal ini karena siswa bisa belajar sesuai dengan kecepatannya sendiri tanpa tergantung pada siswa lain.

Dari aspek manfaat, modul minyak bumi berbasis guided discovery learning yang dikembangkan diperoleh nilai momen kappa yaitu 0,90 dengan kategori sangat tinggi. Data tersebut menggambarkan jika modul yang dikembangkan mampu membantu peran guru sebagai fasilitator dan dapat memudahkan guru memantau kegiatan belajar siswa. Keadaan tersebut didukung oleh penelitian yang menyatakan bahwa pengajaran dengan modul sangat bermanfaat terhadap guru, karena modul dapat mendukung peran guru sebagai fasilitator dan meminimalkan beban kerja guru untuk mengulang-ulang materi ${ }^{[15]}$.

Dari ungkapan di atas diperoleh kesimpulan bahwa modul minyak bumi berbasis guided discovery learning yang dikembangkan dapat dijadikan sebagai bahan ajar dalam proses pembelajaran kimia. Hal tersebut karena modul yang dikembangkan sudah praktis dengan kategori kepraktisan sangat tinggi.

b. Analisis Praktikallitas Berdasarkan Angket Respon siswa

Uji praktikalitas tahap field test dilakukan pada 1 kelas dengan jumlah siswa 24 orang yaitu kelas XII IPA 1 SMAN 8 Padang. Hasil analisis data yang diperoleh melalui angket praktikalitas didapatkan informasi jika modul yang dihasilkan mempunyai 
kategori praktikalitas sangat tinggi dari aspek kemudahan penggunaan, efisiensi waktu serta manfaat secara berturut-turut memiliki momen kappa sebesar 0,86, 0,78 dan 0,83. Hal tersebut juga didukung oleh analisis jawaban siswa saat menggunakan modul yang dapat dilihat pada Tabel 5.

Tabel 5. Analisis jawaban siswa pada modul

\begin{tabular}{c|c|c|c} 
No & $\begin{array}{c}\text { Aspek } \\
\text { Penilaian }\end{array}$ & $\begin{array}{c}\text { Nilai } \\
\text { rata-rata }\end{array}$ & Kategori \\
\hline 1. & $\begin{array}{c}\text { Kemampuan } \\
\text { merumuskan } \\
\text { hipotesis }\end{array}$ & 79,85 & Baik \\
\hline 2. & $\begin{array}{c}\text { Kemampuan } \\
\text { melakukan } \\
\text { pengolahan } \\
\text { data }\end{array}$ & 81,86 & Sangat baik \\
\hline 3. & $\begin{array}{c}\text { Kemampuan } \\
\text { melakukan } \\
\text { verifikasi }\end{array}$ & 80,20 & Sangat baik \\
\hline 4. & $\begin{array}{c}\text { Kemampuan } \\
\text { melakukan } \\
\text { kesimpulan }\end{array}$ & 84,48 & Sangat baik
\end{tabular}

Berdasarkan informasi pada Tabel 5 dapat disimpulkan bahwa secara umum peserta didik mampu belajar menemukan konsep-konsep pada topik kajian minyak bumi dengan menggunakan modul berbasis guided discovery learning yang dibuktikan dengan nilai rata-rata LK semua kelompok termasuk ke dalam kategori baik dan sangat baik.

\section{SIMPULAN}

Kesimpulan yang diperoleh berdasarkan hasil penelitian adalah pengembangan modul minyak bumi berbasis Guided Discovery Learning untuk kelas XI SMA/MA memiliki kategori kevalidan dan kepraktisan yang sangat tinggi.

\section{REFERENSI}

1. Yerimadesi. Model Guided Discovery Learning untuk Pembelajaran kimia (GDL-PK) SMA. 2017;

2. Akinbobola, Akinyemi O, Folashade A. Constructivist practices through guided discovery approach: The effect on students' cognitive achievement in nigerian senior secondary school physycs. 2010;2(1):16-25.

3. Syaifulloh RB, Jatmiko B. Penerapan Pembelajaran Dengan Model Guided Discovery Dengan Lab Virtual PhET untuk Meningktakan Hasil Belajar Siswa Kelas XI di SMA Tuban pada Materi Teori Kinetik Gas. I Inov Pendidik Fis 2014;3(2):174-9.

4. Sari FK, Farida, Syazali M. Pengembangan Media Pembelajaran (Modul) berbantuan Geogebra Pokok Bahasan Turunan. Aljabar. J Pendiidikan Mat 2016;7(2):135-52.
5. Vaino K, Holbrook JH, Rannikmae M. Stimulating students' intrinsic motivation for learning chemistry through the use of contextbased learning modules. Chem Educ Res Pract 2012;13(4):410-9.

6. Nugroho MM, Prayitno BA, Masykuri M. Pengembangan Modul IPA Berbasis Guided discovery learning (GDL) dengan Tema Fotosintesis untuk Meningkatkan Keterampilan Proses Sains Siswa SMP/MTS Kelas VIII SMP Alma'rufiyyah Tempuran. Inkuiry 2018;7(1):151-9.

7. Yerimadesi, Bayharti, Oktavirayanti V. Validitas dan Praktikalitas Modul Reaksi Redoks dan Sel Elektrokimia Berbasis Guided discovery learning untuk SMA. I Eksakta Pendidik 2018;2(1):17$\underline{24}$.

8. Plomp T, Nieveen N. Education Design Research. Ensschede Netherland: National Institute for Curriculum Development (SLO); 2010.

9. Suryosubroto B. Sistem Pengajaran dengan Modul. Yogyakarta: Bina Aksara; 1983.

10. Departemen Pendidikan Nasional. Panduan Pengembangan Bahan Ajar. Jakarta: Departemen Pendidikan Nasional, Direktorat Lenderal Manajemen Pendidikan Dasar dan Menengah, Direktorat Pembinaan Sekolah Menengah Atas; 2008.

11. Boslaugh S dan PAW. Statistics in a Nutshell, a desktop quick reference. Beijing, Cambridge, Famham, Köln, Sebastopol, Taipei,Tokyo: O'reilly;

12. Riduwan. Metode dan Teknik Penyusunan Proposal Penelitian. Bandung: Alfabeta; 2015.

13. Majid A. Perencanaan Pembelajaran. Bandung: Remaja Rosdakarya; 2013.

14. Sugiyono. Metode Penelitian Pendidikan (Kuantitatif, Kualitatif, dan R\&D). Bandung: Alfabeta; 2017.

15. Khotim HN, Nurhayati S, Hadisaputro S. Pengembangan Modul Kimia Berbasis Masalah Pada Materi Asam Basa. CiE 2015;4(2):64-9.

16. Yerimadesi, Bayharti, Handayani F, Legi WF. Pengembangan Modul Kesetimbangan Kimia Berbasis Pendekatan Saintifik untuk Kelas XI SMA/MA. I Sainstek 2016;8(1):85-97.

17. Andrean MD, Yerimadesi, Gazali F.Validitas dan Praktikalitas Modul Sistem Koloid Berorientasi Chemo-Entrepreneurship (CEP) untuk Kelas XI IPA SMA/MA. Edukimia 2019;1(2):62-28.

18. Yerimadesi, Bayharti, Jannah SM, Lufri, Festiyed, Kiram Y. Validity and Practitality of Acid-Base Module Based on Guided discovery learning for Senior High School. IOP Conf Ser 2018;335(012097).

19. Mulyasa E. Kurikulum yang disempurnakan: pengembangan standar kompetensi dan kompetensi dasar. Bandung: Remaja Rosdakarya; 2006. 